\title{
The Financial Crisis: Lessons for International Macroeconomicsi
}

\author{
By Matthieu Bussière, Jean Imbs, Robert Kollmann, \\ AND ROMAIN RANCIÈRE*
}

\begin{abstract}
This article introduces a special section of the American Economic Journal: Macroeconomics, containing five papers presented during a conference in Paris in October 2011. The aim of the conference was to derive lessons from the financial crisis, for research on international macroeconomics and for policy. The article opens with a summary of the key mechanisms at play during the crisis. The question of the crisis transmission across borders is addressed, with a focus on international trade and financial institutions. Recent advances in the analysis of sovereign default risk are also discussed. The article concludes with a discussion of policy responses to the crisis. (JEL E32, E44, F14, G01, G21, G28)
\end{abstract}

W hen the financial crisis erupted in 2008, it triggered a sharp global contraction of real activity, and durably transformed the international economic environment. Virtually no country or market was left unaffected. In many advanced economies, these dramatic events were countered by sizable fiscal stimulus measures and by massive interventions by governments and central banks to support key financial institutions. The crisis has highlighted the need for a better understanding of the international transmission channels of economic disturbances, and for more efficient policy responses to large shocks in the presence of strong cross-country linkages and dysfunctional financial markets.

This special section of the American Economic Journal: Macroeconomics consists of five papers that address these challenges. The papers were presented during a conference organized in Paris on October 28-29, 2011, under the auspices of Banque de France, the Paris School of Economics, ECARES (Université Libre de Bruxelles), the American Economic Association, and the Centre for Economic Policy Research (CEPR). These papers cover a broad range of questions-the

\footnotetext{
* Bussière: Banque de France, Banque de France, 49-1374 DERIE-SEMSI, 75049 Paris, France (e-mail: matthieu.bussiere@banque-france.fr); Imbs: Paris School of Economics, 106 Bvd de l'Hopital-75013 Paris, France, Centre National de la Recherche Scientifique (CNRS), and Centre for Economic Policy Research (CEPR) (e-mail: Jean.Imbs@parisschoolofeconomics.eu); Kollmann: European Centre for Advanced Research in Economics and Statistics (ECARES), Université Libre de Bruxelles, CP 114, 50 Avenue Franklin Roosevelt B-1050 Brussels, Belgium and Université Paris-Est, and Centre for Economic Policy Research (CEPR) (e-mail: robert_kollmann@ yahoo.com); Rancière: Paris School of Economics (ENPC), 106 Bvd de l'Hopital-75013, Paris, France and Centre for Economic Policy Research (CEPR) (e-mail: Romain.Ranciere@parisschoolofeconomics.eu). The views expressed in this paper are those of the authors and do not necessarily reflect those of the Banque de France or the Eurosystem.

${ }^{\dagger}$ Go to http://dx.doi.org/10.1257/mac.5.3.75 to visit the article page for additional materials and author disclosure statement(s) or to comment in the online discussion forum.
} 
International correlation of monthly industrial production 24 OECD countries, 1980-2010, 3-year windows

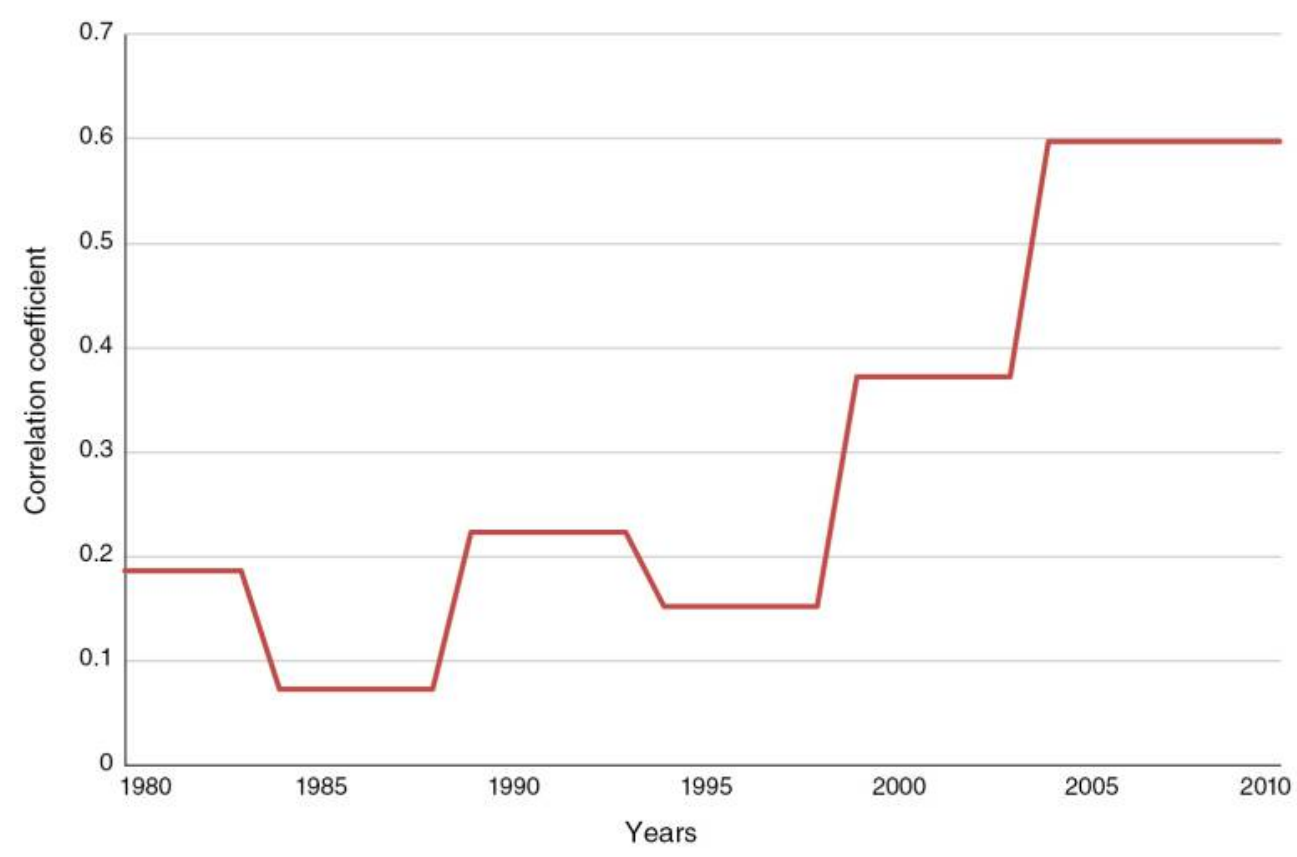

Figure 1. Synchronization of GDP Growth

collapse in world trade, global financial institutions as a channel for international crisis transmission, sovereign risk-and also address policy options for crisis prevention and crisis resolution.

\section{Crisis Mechanisms and International Transmission}

One of the striking aspects of the 2008 financial crisis was the pronounced and synchronized slowdown in real activity, suggesting that contagion across countries has been particularly powerful. Figure 1 plots the average pairwise, cross-country correlation of industrial production for 24 Organisation for Economic Co-operation and Development (OECD) countries, across 3-year windows (1980-2010), as reported by Imbs (2010). The average correlation for the period 2007-2010 is about 0.6 , markedly above pre-crisis correlations. Although substantial cross-country spillovers were to be expected given the tight integration of world markets after several decades of globalization, the speed and strength of the financial and trade channels represent a challenge for research.

\section{The Collapse in World Trade}

During the financial crisis, the growth rate of world trade has fallen much more than world GDP growth (see Figure 2). In this special issue, Bussière et al. (2013), use a panel of 18 OECD countries to explain the collapse in trade, and consider the 


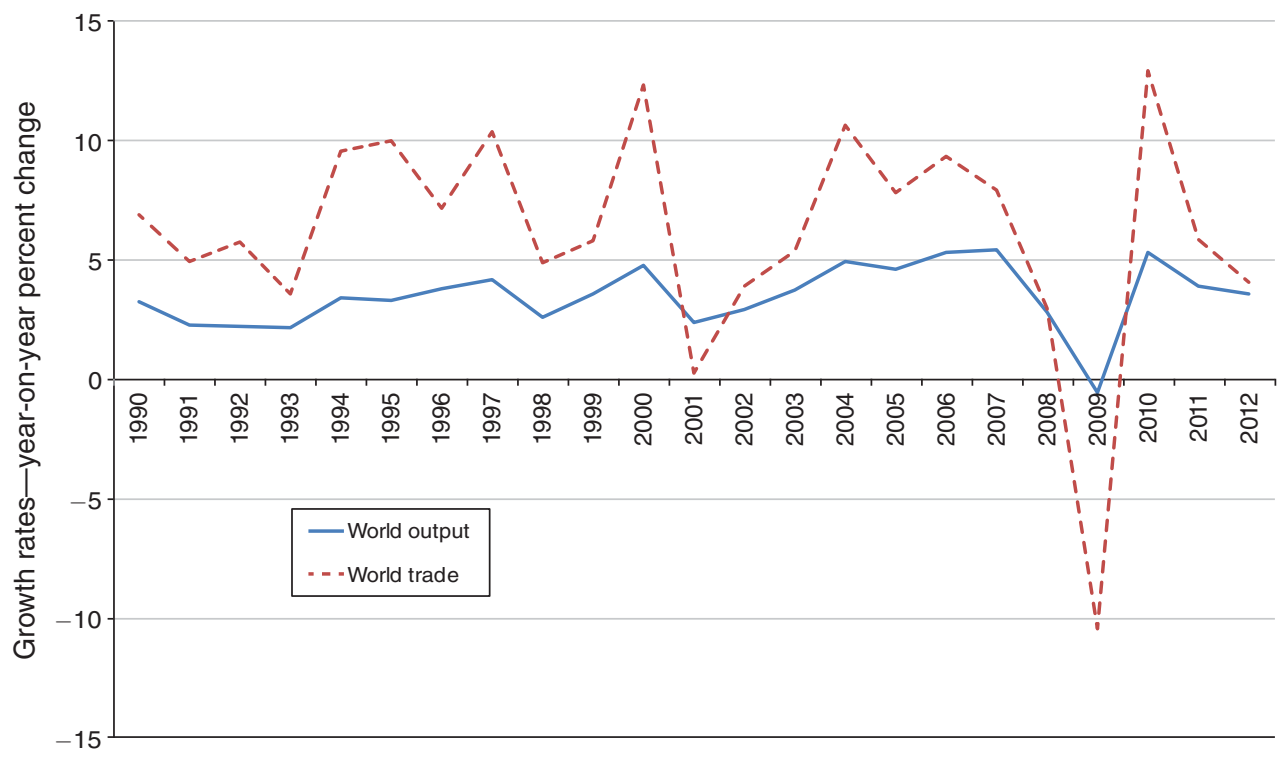

Figure 2. Trade Collapse

importance of the contraction in trade as an international transmission channel. The key contribution of the paper is to use input-output tables to estimate the trade intensity of the components of aggregate demand. The authors show that investment and exports are markedly more import intensive than private consumption and government purchases. This is particularly important in the context of the crisis, as investment fell much more strongly (in relative terms) than other demand components. The authors calculate a new measure of aggregate demand that reflects the import intensity of GDP components. This demand measure captures fluctuations in world trade much better than GDP, especially during recessions.

The findings of Bussière et al. (2013) are complementary to other papers on the "Great Trade Collapse" (Baldwin 2009) during the recent financial crisis. See, for example, Levchenko, Lewis, and Tesar (2010), who argue that trade in intermediate inputs fell especially sharply during the crisis (note that the intermediate-goods intensity of investment is particularly high). Eaton et al. (2011) also use input-output tables to derive the component of expenditure falling on intermediate goods. They conclude that demand composition shocks are the most important drivers of the collapse in global trade, with trade frictions playing a much more limited role. Differently from these papers, Bussière et al. (2013) focus on the composition of aggregate demand rather than on the composition of trade flows. Finally, Alessandria, Kaboski, and Midrigan (2010), focusing on US trade, show that inventory adjustments likely amplified the fall in world trade during the crisis. Since inventories are a highly volatile component of investment, that result is in line with the importance of the investment channel stressed by Bussière et al. (2013).

Financial shocks have also contributed to the disruption of international trade, through two main channels. First, the financial crisis has adversely affected exporting and importing firms, which depend on credit markets to fund their operations (in that respect those firms are not different from other firms). Second, the financial crisis 




Figure 3. Retrenchment in Cross-Border Banking Flows

Source: Committee on the Global Financial System (2011)

has directly reduced international trade by lowering access to trade finance. The role of financial shocks is highlighted in several key papers. Amiti and Weinstein (2011) focus on the link between distressed banks and exporting firms that borrow from those banks. Chor and Manova (2012) demonstrate that US imports during the crisis fell more for sectors and trading partners for which financing conditions were tighter (see Bussière et al. 2013 and Bems, Johnson, and Yi 2012 for further discussions of these issues).

\section{Financial Institutions as a Channel of International Crisis Transmission}

Financial linkages among financial institutions also served as an important channel in the transmission of shocks across borders. During the 2008 financial crisis, cross-border financial flows fell sharply, after having grown strongly during the previous decades (Figure 3). The pre-crisis workhorse open-economy macroeconomic models mostly assumed frictionless global financial markets and efficient international risk sharing, and largely abstracted from banks. The crisis has revealed the inadequacy of those theories, and triggered new research that incorporates banks and other highly leveraged financial institutions into dynamic open economy models. This new class of models builds on the observation that, in a globalized financial system, banks hold domestic and foreign assets. An adverse macroeconomic or financial shock in one country that lowers the capital of global banks may thus trigger a global asset sell-off and a global decrease in bank lending (credit crunch), thereby precipitating a global recession.

Financial institutions are sensitive to relatively small declines in asset prices because the bulk of their assets is financed by short-term liabilities. Banks' internal funds (i.e., bank capital) only account for a small fraction of total assets. The 
capital/asset ratios of the major European banks and of major US investment banks have typically ranged between 3 percent and 5 percent in the period 1995-2010, while the capital ratios of US commercial banks have generally been in the range of 7 percent to 8 percent. Furthermore, bank assets generally have a longer maturity and are less liquid than bank liabilities. This was a source of fragility that magnified the effect of the financial crisis.

Krugman (2008) sketched a static, bare bones model of an "international financial multiplier" in which asset price changes are transmitted internationally through the balance sheets of highly levered global financial institutions (these can be viewed as banks or hedge funds). The key ingredient of the finance multiplier is the assumption that levered investors have to back at least a fraction of their assets using their own funds (capital/net worth): capital/assets $\geq \kappa$, for some coefficient $0<\kappa<1$. Such a "capital constraint" can reflect a regulatory requirement or market pressures. If the expected return on bank assets exceeds the interest rate on debt, then levered investors have an incentive to borrow the maximum amount, and thus the capital ratio will stay close to the required capital ratio. An unanticipated initial fall by $\$ 1$ in the value of the assets held by a leveraged investor in one country lowers the investor's net worth by $\$ 1$. If the leverage constraint binds, then levered investors have to lower asset holdings and debt by $\$(1-\kappa) / \kappa$. For low values of $\kappa$, the ensuing reduction of asset holdings and debt positions of levered investors are thus sizable. If leveraged investors hold global asset portfolios, this can trigger a vicious circle of global deleveraging and falling asset prices. A similar powerful effect operates when asset values rise to contribute to asset bubbles. Yet, while the intuition stands in a reduced-form model, clearly a general equilibrium model is needed for a coherent analysis of these effects - a consistent story has to spell out who buys the assets sold by "banks" (leveraged investors).

Van Wincoop's (2012) paper, included in the special issue, provides a theoretical analysis of an "international financial multiplier," based on a simple two-period model of a two-country world. Van Wincoop studies the effect of an exogenous negative wealth shock suffered by leveraged investors. Crucially, he assumes the presence of unlevered investors who can arbitrage between risky and risk-free assets. The negative wealth shock triggers a sale of risky assets by levered investors to the unlevered investors. As the latter are more risk averse than levered investors, domestic and foreign equity prices fall. However, due to arbitrage, the risk-adjusted return on risky assets is equated to the risk-free interest rate. As risk premia are small in the model (as in other standard macro models), the fall in equity prices is negligible; also, only a small fraction of a fall in asset prices is transmitted abroad. In other terms, the "international financial multiplier" is very weak.

Other recent studies have presented models with markedly more powerful international multiplier effects of shocks to the net worth of leveraged financial institutions. The key ingredient for these stories is the assumption that buyers of distressed assets have less expertise to manage those assets, or that those buyers are credit constrained; see, e.g., Devereux and Sutherland (2011). Several recent papers have also developed open economy models in which negative shocks to bank capital lead to a reduction in the supply of loans, and thus to a fall in domestic and foreign investment and output; see, e.g., Kollmann, Enders, and Müller (2011); Perri 
10-year government bond spreads versus Bund



Figure 4. Rise of Sovereign Spreads

and Quadrini (2011); and Mendoza and Quadrini (2010). Empirical evidence of a cross-country bank credit channel is provided by Kollmann (2012).

\section{The Rise of Sovereign Default Risk in Advanced Economies}

One of the major consequences of the crisis has been the re-emergence of sovereign default risk in advanced economies, particularly in the Euro area. Between the adoption of the Euro and the crisis of 2008, investors treated all sovereign bonds issued in the Euro area as basically default-free. Indeed, as shown in Figure 4, sovereign bond spreads among European countries before the fall of 2008 were minuscule, and remained below or close to $100 \mathrm{bps}$ until the end of 2008. While in 2009 and 2010 sovereign spreads between the south and the north of Europe increasingly diverged, the idea that a Euro-area country could be forced to request a restructuring of its public debt was still deemed unacceptable by key policymakers. In 2011, however, several Euro area countries started to experience spreads above $500 \mathrm{bps}$, a clear indication that default risk was now a primary concern for investors. Finally, in October 2011, Greek bondholders agreed to a large debt exchange with an announced haircut of 50 percent. Since then, the possibility that other European countries might follow the same path remains an important policy issue.

While default risk remains at the forefront of policy concerns, the existing empirical literature on the measurement of creditor losses (haircuts) and on their consequences for reaccessing international debt markets, and for future costs of borrowing, is relatively scant. Due to the absence of systematic empirical evidence, the literature often makes heroic assumptions about creditor behavior. For example, before the crisis, common wisdom reflected the view of Bulow and Rogoff (1989) that "debt which is forgotten will be forgiven," i.e., the notion that countries that 
default do not suffer from a substantially higher cost of borrowing after a debt crisis, and often regain access to international credit markets one or two years after a default. The lack of robust empirical evidence on the costs and consequences of sovereign default is also a source of disconnect between the empirical and theoretical literature on sovereign default. For example, most theoretical default models in the style of Arellano (2008) assume a 100 percent haircut on defaulted debt, disregarding the evidence that sovereign default is always partial, with creditor losses varying across default episodes.

Sturzenegger and Zettelmeyer (2006) revamped the empirical literature in the area, by developing the novel and robust approach of computing haircuts based on the ratio of the present value of payments by debtors after debt renegotiation relative to the present value of original contractual payment obligations.

In a paper presented in this special issue, Cruces and Trebesch (2013) considerably extend the work of Sturzenegger and Zettelmeyer (2006) by providing the first complete database of haircuts for all defaults and restructuring episodes between 1970 and 2010. This database is in itself an important contribution and a key resource for future empirical and theoretical research on sovereign debt. The authors go to great lengths to contrast their results with the previous literature. They uncover three important new patterns: (i) haircuts do not differ, on average, among different type of creditors (banks versus bond holders); (ii) haircuts differ widely by the development status of debtor countries (haircuts in Heavily Indebted Poor Countries (HIPC) were, on average, 87 percent, while only 29 percent in all the other countries); (iii) haircuts in the second half of the sample (1990-2010) are twice as large as in the first half of the sample ( 50 percent versus 25 percent), while the number of default/restructuring events was the same. These findings suggest a link between international financial integration and the severity of default episodes.

Cruces and Trebesch (2013) also examine the link between the severity of creditor losses, the cost of future borrowing, and the length of market exclusion. Here, the two key findings are that default episodes with large haircuts are associated with (i) high future sovereign spreads, and (ii) long periods of market exclusion. These results stand in sharp contrast with the previous evidence in the literature, and question not only the conventional wisdom of Bulow-Rogoff, but also more recent empirical and theoretical work (Benjamin and Wright 2009). The effect of a large haircut on sovereign spreads is both important and long-lasting. A 1 standard deviation increase in the imposed haircut — calculated as 27 percentage points-is associated with an increase in spreads of $149 \mathrm{bps}$ in year 1 and $70 \mathrm{bps}$ in year 5 . The effect of a large haircut on the future ability to issue debt is also sizable. Almost all countries with a haircut of 30 percentage points or less are able to reenter capital markets within 5 years, while 50 percent of the countries with a haircut of 60 percentage points or more are still excluded after 10 years.

The authors are careful to note the limitations of their estimation methodology. They cannot completely rule out that unobserved, time-varying country characteristics drive their results. They point out that while their results are consistent with models in which default generates reputation costs or market-based sanctions, their methodology is not a direct structural test of such models. Nevertheless, this new set of evidence will certainly have a profound influence on theoretical models of 
Central banks' interest rates

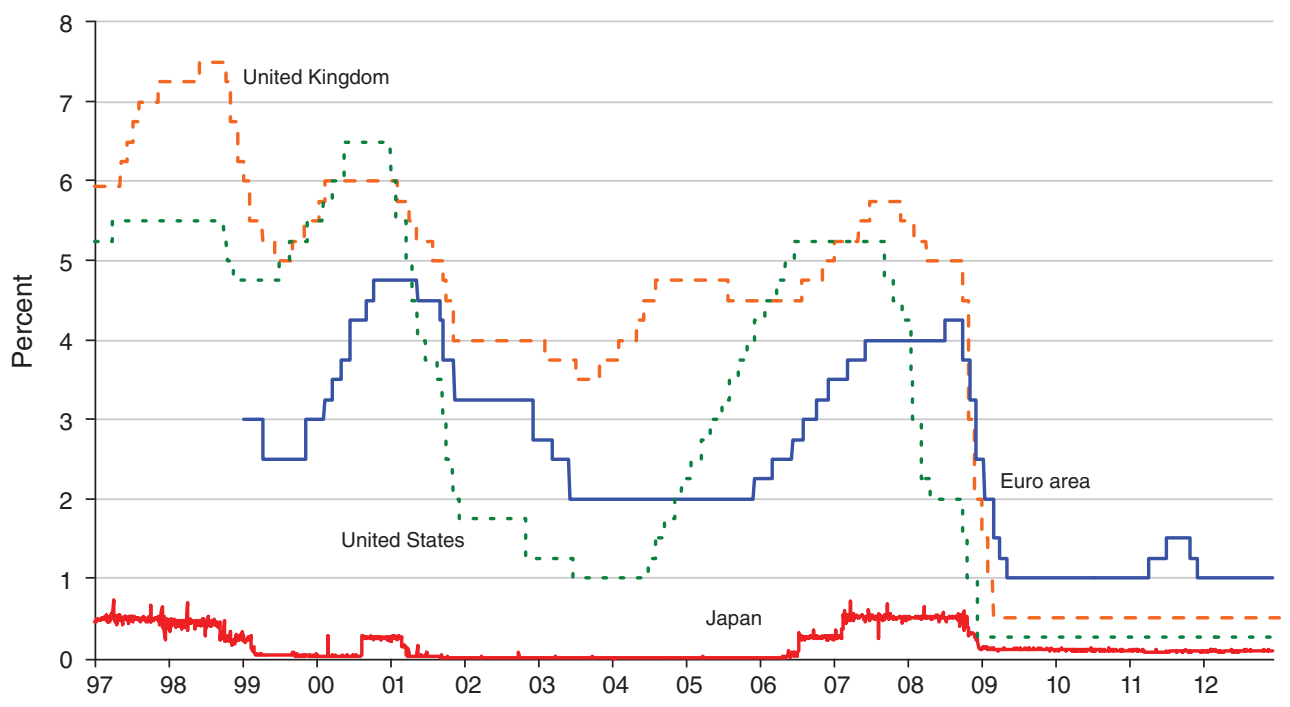

Figure 5. Policy Interest Rates by Major Central Banks

sovereign default. The data may be particularly useful for testing dynamic stochastic general equilibrium frameworks, such as Asonuma (2012). Asonuma (2012) proposes a framework that explicitly models renegotiations between a defaulting country and its creditors, and shows that a country for which default terms require less than a 100 percent recovery rate tends to pay a higher rate of return (relative to a risk-free rate) on debt that is issued subsequently than do defaulting countries that agree to a full recovery rate.

\section{Policy Response: Crisis Prevention and Resolution}

The financial crisis necessitated innovative and dramatic policy interventions by governments and central banks across the world. In particular, during the crisis, central banks in industrialized countries have lowered their policy rates rapidly and sharply (see Figure 5). While the Bank of Japan's policy rate has been close to zero since the Japanese financial crisis of 1990, in the United States and the United Kingdom, the policy rate was cut to 50 basis points or less. The ECB lowered its policy rate to 1 percent. Interestingly, the ECB cut its policy rate both less aggressively and at a later date than the Fed and the Bank of England, despite similar real economic conditions. In this special issue, Cook and Devereux (2012) provide an interpretation of these cross-country differences in policy responses to the financial crisis. The authors analyze optimal monetary and fiscal policy in a two-country world, when a negative demand shock in one country pushes that country into a liquidity trap (zero interest rate). As the negative demand shock lowers the expected inflation rate in the source country, its real interest rate rises, and thus the source country's real exchange rate appreciates (due to real interest rate parity), which exacerbates the slump in that country. Cook and Devereux show the policy that 
maximizes the joint welfare of the two countries requires the foreign central bank to keep its policy rate above that of the source country; this dampens the appreciation of the real exchange rate of the source country, and thus alleviates the slump. Even when central banks act noncooperatively (i.e., solely seek to maximize national welfare), the foreign monetary policy is tighter than source country policy, in order to combat the rise in foreign inflation due to the foreign real exchange rate appreciation. Optimal policy also calls for strong fiscal stimulus in the source country, and for a more muted fiscal expansion in the other country.

During the past two decades key emerging economies ran persistent and large current account surpluses. An influential academic view interprets those surpluses as the result of financial frictions in emerging economies. According to this view, the limited supply of safe financial assets in those economies (Caballero, Farhi, and Gourinchas 2008), or the strong demand for such assets by emerging economies, stemming from precautionary saving with incomplete financial markets (Mendoza, Quadrini, and Ríos-Rull 2009), both result in excess private saving and positive net foreign asset holdings. This mechanism does not explain why the foreign assets accumulated by emerging economies are often held by the central banks of those countries in the form of international reserves, and not by the private sector.

In this special issue, Bacchetta, Benhima, and Kalantzis (2013) explain this phenomenon using a model of a semi-open economy, that is, an economy where the central bank has access to international capital markets, but the private sector has not. The authors consider an economy where financial frictions generate a low supply of and a large demand for safe saving instruments by the private sector, and they study the optimal policy of the central bank. The central bank can provide saving instruments to the domestic financial market, and use the proceeds to buy international reserves. By doing so, it intermediates the need for external saving by the private sector.

Bacchetta, Benhima, and Kalantzis (2013) find that, with strong enough domestic financial frictions, it is always optimal for the central bank to accumulate foreign reserves. However, the optimal level of reserves is not necessarily the one that would obtain in an open economy, where the private sector could directly access foreign financial markets. In a catching-up economy, it is optimal for the central bank to set the domestic interest rate above the world interest rate, as this subsidizes saving and helps domestic private agents accumulate wealth, which relaxes their future borrowing constraint. Thus, imposing capital controls and hoarding international reserves are two parts of an integrated policy.

\section{REFERENCES}

-Alessandria, George, Joseph P. Kaboski, and Virgiliu Midrigan. 2010. "The Great Trade Collapse of 2008-09: An Inventory Adjustment?" IMF Economic Review 58 (2): 254-94.

-Amiti, Mary, and David E. Weinstein. 2011. "Exports and Financial Shocks." Quarterly Journal of Economics 126 (4): 1841-77.

-Arellano, Cristina. 2008. "Default Risk and Income Fluctuations in Emerging Economies." American Economic Review 98 (3): 690-712.

Asonuma, Tamon. 2012. "Serial Default and Debt Renegotiation." Unpublished.

- Bacchetta, Philippe, Kenza Benhima, and Yannick Kalantzis. 2013. "Capital Controls with International Reserve Accumulation: Can This Be Optimal?" American Economic Journal: Macroeconomics 5 (3): 229-62. 
Baldwin, Richard, ed. 2009. The Great Trade Collapse: Causes, Consequences and Prospects. London: Center for Economic and Policy Research. VoxEU.org ebook.

Bems, Rudolfs, Robert C. Johnson, and Kei-Mu Yi. 2012. "The Great Trade Collapse." National Bureau of Economic Research (NBER) Working Paper 18632.

Benjamin, David, and Mark L. J. Wright. 2009. "Recovery Before Redemption? A Theory of Delays in Sovereign Debt Renegotiations." http://www.aeaweb.org/aea/2011conference/program/retrieve. php?pdfid=72.

Bulow, Jeremy, and Kenneth Rogoff. 1989. "Sovereign Debt: Is to Forgive to Forget?" American Economic Review 79 (1): 43-50.

Bussière, Matthieu, Giovanni Callegari, Fabio Ghironi, Giulia Sestieri, and Norihiko Yamano. 2013. "Estimating Trade Elasticities: Demand Composition and the Trade Collapse of 2008-2009." American Economic Journal: Macroeconomics 5 (3): 118-51.

- Caballero, Ricardo J., Emmanuel Farhi, and Pierre-Olivier Gourinchas. 2008. “An Equilibrium Model of 'Global Imbalances' and Low Interest Rates.” American Economic Review 98 (1): 358-93.

-Chor, Davin, and Kalina Manova. 2012. "Off the cliff and back? Credit conditions and international trade during the global financial crisis." Journal of International Economics 87 (1): 117-33.

Committee on the Global Financial System. 2011. Global liquidity-concept, measurement and policy implications. Committee on the Global Financial System (CGFS) Paper 45. Basel, November.

- Cook, David, and Michael B. Devereux. 2013. "Sharing the Burden: Monetary and Fiscal Responses to a World Liquidity Trap." American Economic Journal: Macroeconomics 5 (3): 190-228.

-Cruces, Juan J., and Christoph Trebesch. 2013. "Sovereign Defaults: The Price of Haircuts." American Economic Journal: Macroeconomics 5 (3): 85-117.

Devereux, Michael B., and Alan Sutherland. 2011. "Evaluating international financial integration under leverage constraints." European Economic Review 55 (3): 427-42.

Eaton, Jonathan, Samuel Kortum, Brent Neiman, and John Romalis. 2011. "Trade and the Global Recession." National Bureau of Economic Research (NBER) Working Paper 16666.

Feenstra, Robert C. 2003. Advanced International Trade: Theory and Evidence. Princeton: Princeton University Press.

Imbs, Jean. 2010. “The First Global Recession in Decades.” IMF Economic Review 58 (2): 327-54.

Kollmann, Robert. 2012. "Global Banks, Financial Shocks and International Business Cycles: Evidence from an Estimated Model." Center for Economic and Policy Research (CEPR) Discussion Paper 8985.

Kollmann, Robert, Zeno Enders, and Gernot J. Müller. 2011. "Global banking and international business cycles." European Economic Review 55 (3): 407-26.

Krugman, Paul. 2008. “The International Finance Multiplier.” http://www.princeton.edu/ pkrugman/ finmult.pdf.

Levchenko, Andrei A., Logan T. Lewis, and Linda L. Tesar. 2010. "The Collapse of International Trade during the 2008-09 Crisis: In Search of the Smoking Gun." IMF Economic Review 58 (2): 214-53.

-Mendoza, Enrique G., and Vincenzo Quadrini. 2010. "Financial globalization, financial crisis and contagion." Journal of Monetary Economics 57 (1): 24-39.

-Mendoza, Enrique G., Vincenzo Quadrini, and José-Victor Ríos-Rull. 2009. "Financial Integration, Financial Development, and Global Imbalances.” Journal of Political Economy 117 (3): 371-416.

Perri, Fabrizio, and Vincenzo Quadrini. 2011. "International Recessions." http://faculty.chicagobooth. edu/workshops/macro/past/pdf/Paper-April-15-2011.pdf.

Sturzenegger, Federico, and Jeromin Zettelmeyer. 2006. Debt Defaults and Lessons from a Decade of Crises. Cambridge, MA: MIT Press.

van Wincoop, Eric. 2013. "International Contagion through Leveraged Financial Institutions." American Economic Journal: Macroeconomics 5 (3): 152-189. 